$11-9-2016$

\title{
Numerical investigation of novel microwave applicators based on zero-order mode resonance for hyperthermia treatment of cancer
}

\author{
David Vrba \\ Czech Technical University in Prague \\ Jan Vrba \\ Czech Technical University in Prague
}

Dario B. Rodrigues

Thomas Jefferson University

Paul R. Stauffer

Thomas Jefferson University

Follow this and additional works at: https://jdc.jefferson.edu/radoncfp

Part of the Oncology Commons, and the Radiology Commons

Let us know how access to this document benefits you

\section{Recommended Citation}

Vrba, David; Vrba, Jan; Rodrigues, Dario B.; and Stauffer, Paul R., "Numerical investigation of novel microwave applicators based on zero-order mode resonance for hyperthermia treatment of cancer" (2016). Department of Radiation Oncology Faculty Papers. Paper 83.

https://jdc.jefferson.edu/radoncfp/83

This Article is brought to you for free and open access by the Jefferson Digital Commons. The Jefferson Digital Commons is a service of Thomas Jefferson University's Center for Teaching and Learning (CTL). The Commons is a showcase for Jefferson books and journals, peer-reviewed scholarly publications, unique historical collections from the University archives, and teaching tools. The Jefferson Digital Commons allows researchers and interested readers anywhere in the world to learn about and keep up to date with Jefferson scholarship. This article has been accepted for inclusion in Department of Radiation Oncology Faculty Papers by an authorized administrator of the Jefferson Digital Commons. For more information, please contact: JeffersonDigitalCommons@jefferson.edu. 


\title{
Numerical Investigation of Novel Microwave Applicators Based on Zero-Order Mode Resonance for Hyperthermia Treatment of Cancer
}

\author{
David Vrba $^{a *}$, Jan Vrba ${ }^{a}$, Dario B. Rodrigues ${ }^{b}$, Paul Stauffer ${ }^{b}$ \\ ${ }^{a}$ Faculty of Biomedical Engineering, Czech Technical University in Prague, Zikova 4, 16636 Prague, Czech Republic \\ ${ }^{b}$ Radiation Oncology Dept., Thomas Jefferson University, Bodine Cancer Center 111 S. 11th. St.Philadelphia PA 19107, USA
}

\begin{abstract}
This paper characterizes three novel microwave applicators based on zero-order mode resonators for use in hyperthermia treatment of cancer. The radiation patterns are studied with numerical simulations in muscle tissue-equivalent model at $434 \mathrm{MHz}$. The relative performance of the applicators is compared in terms of reflection coefficient, current distribution, power deposition (SAR) pattern, effective field size in 2D and 3D tissue volumes, and penetration depth. One particular configuration generated the most uniform SAR pattern, with $25 \%$ SAR covering $84 \%$ of the treatment volume extending to $1 \mathrm{~cm}$ depth under the aperture, while remaining above $58 \%$ coverage as deep as $3 \mathrm{~cm}$ under the aperture. Recommendations are made to further optimize this structure.
\end{abstract}

Keywords: Microwave hyperthermia, zero-order mode resonator, metamaterial applicator, power deposition.

\section{Introduction}

Metamaterial (MTM) Zeroth-Order mode resonators (ZOR) have been recently introduced and shown potential to improve thermotherapy of cancer [1]. These can be integrated in antenna applicators by improving the homogeneity of electromagnetic (EM) power deposition and the depth of EM wave penetration in tissue under the antenna aperture. With proper assembly, ZOR resonators can improve the homogeneity of heating of large areas or conversely localize EM power within well-defined small regions [2]. In addition, ZOR resonators allowthe creation of electrically small applicators that work without filling its structure with high dielectric water typical of current clinical applicators [REF]. The resultant thinner structure could facilitate the delivery of microwave hyperthermia treatments simultaneous with 3D monitoring of tissue temperature distribution using Magnetic Resonance (MR) thermal imaging which is subject to artefacts from circulating water $[\mathrm{REF}]$.

A major advantage of the ZOR phenomenon is that it enables the development of a special kind of resonator whose physical length is completely independent of the classical resonance condition (wavelength), as described in [3]. The phase constant $\beta=0$ ( $x$ axis of Fig. 1a) in this case implies infinite guided wavelength $\lambda_{g}=2 \pi /|\beta|$ along the MTM structure as well as zero phase shift $(\theta m=-\beta l=0)$ [3]. On the dispersion diagram of Fig. 1a, one can observe the positive (classical $\lambda / 2, \lambda$ and $3 \lambda / 2$ ) resonances $f_{1}, f_{2}$ and $f_{3}$ and negative resonances $f_{-1}, f_{-2}, f_{-3}$, which correspond to the modes $m=-1, m=-2$ and $m=-3$ in Fig. $1 b$, respectively. Since the Zeroth Order Mode is not dependent on the classical resonant condition of $\lambda / 2$

*Corresponding author. Tel.: +420604158209

E-mail address: david.vrba@fbmi.cvut.cz. 
multiplies, this allows us to design the applicator with dimensions matching the clinical need. Moreover, as a result of the spatial arrangement of MTM resonators, the radiation pattern approximates an almost perfect electromagnetic plane wave as it emerges from the aperture and radiates into tissue. This improvement in wave propagation produces the advantage of optimizing homogeneity of power deposition under the aperture with corresponding improvement in uniformity of the temperature distribution throughout the target volume.

In this paper, relevant properties of three novel microwave applicators based on ZOR phenomenon are investigated for use in hyperthermia cancer treatment. Each applicator is modeled using an established commercial numerical simulator, COMSOL Multiphysics (COMSOL AB, Stockholm, Sweden). Relative performance of the three applicators is compared with respect to the homogeneity of power deposition virtually induced in numerical muscle tissue-equivalent model.
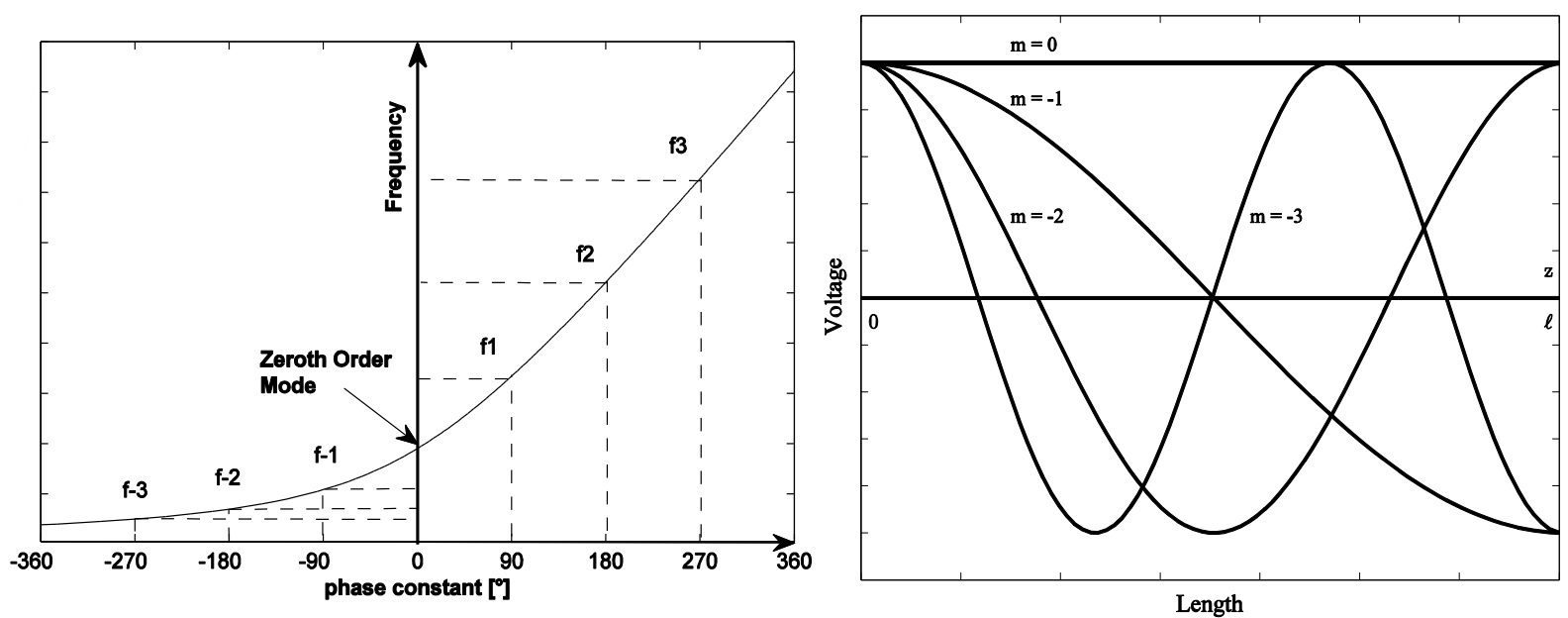

Fig. 1. Relation of the transmission line (TL) and resonant frequencies $f$ of the corresponding resonator (a). Voltage distribution in the case of open-circuited TL of length $\ell$ (b). Mode $m=0$ represents the ZOR with infinite guided wavelength.

\section{Applicator design}

Three novel MTM applicators were designed for hyperthermia treatments at $434 \mathrm{MHz}$ based on similar ZOR working principles. By exciting the zero-order mode, current density vectors are generated in the tissue facing inductive components of the applicators with approximately the same magnitude and phase. The radiated contributions from all inductive parts of the applicator are constructively added as they exit the front aperture of the applicator and combine in phase in tissue. This allows the Huygens principle to be applied to describe the resulting EM field distribution in tissue.

The first step in the applicator design is to estimate preliminary values of all equivalent circuit elements of a single MTM unit cell [3-4]. This includes initial estimates for the inductive radiating element dimensions, tuning capacitance, and dielectric constant of the substrate. Each unit cell consists of an artificially inserted series interdigital capacitor $C_{\mathrm{L}}$ and parallel shunt inductor $L_{\mathrm{L}}$ (subscript $L$ denotes left-handed properties), which are evaluated according to empirical approximate relations. The value of $C_{\mathrm{L}}(\mathrm{pF})$ is calculated according to [5] by using the following equations

$C_{\mathrm{L}}=\frac{\epsilon_{\mathrm{r}}+1}{w_{\mathrm{p}}} l\left[(n-3) A_{1}+A_{2}\right]$ 
$A_{1}=\frac{1}{25.4}\left[0.3349057-0.15287116\left(\frac{h}{x}\right)^{-1}\right]^{2} A_{1}=\frac{1}{25.4}\left[0.50133101-0.22820444\left(\frac{h}{x}\right)^{-1}\right]^{2} x=w_{p}=s$

where $n$ is a number of interdigital arms, $l$ is the length of fingers, $w_{\mathrm{p}}$ is width of finger, $h$ is the height above the ground plane and $s$ is width of the gap between fingers.

Assuming a wire construction, the inductance of $L_{\mathrm{L}}$ can be calculated according to [6] as follows:

$L_{\mathrm{L}}=\frac{\mu_{0}}{2 \pi}\left[l_{\text {ind }} \ln \left(\frac{l_{\text {ind }}+\sqrt{r^{2}+l_{\text {ind }}^{2}}}{r}\right)+\frac{3}{2}\left(r-\sqrt{r^{2}+l_{\text {ind }}^{2}}\right)\right]$

where $l_{\text {ind }}$ is length of inductive parts of structures (denoted in yellow in Fig. 6) and $r$ is its radius. For cases where $L_{\mathrm{L}}$ is represented as a microstrip line, it can be determined using:

$L_{\mathrm{L}}=L_{\mathrm{S}}=0.2 l_{\text {ind }}\left(\log \frac{2 l_{\text {ind }}}{w_{\mathrm{s}}+t}\right)+0.5+0.2235\left(\frac{w_{\mathrm{s}}+t}{l_{\text {ind }}}\right)$

where $w_{\mathrm{s}}$ is the width of the strip and $t$ is thickness of the metal.

The final applicator design is a result of a parametric optimization using numerical simulations. The critical inductive elements that generate the radiating wave are highlighted in yellow in Figs. 2-4.The simulations were performed using a very fine mesh, where the maximum element size (the edge of the tetrahedral) was set to $7 \mathrm{~mm}$ which corresponds approximately to $1 / 100 \lambda_{0}$, where $\lambda_{0}$ is the free space wavelength for $434 \mathrm{MHz}$. Computational time was about 20 minutes for one frequency point with a PC equipped with CPU Intel 6-core i7-3930K and 48 ? Gb of RAM.

The first proposed applicator (applicator 1) is based on micro-coplanar technology with four MTM unit cells (Fig. 2). The micro-coplanar transmission line consists of widely spaced signal and referred ground conductors. This design includes a ground plane under the substrate which suppresses backside radiation from the applicator. More detailed description of a similar structure developed for telecommunication purposes can be found in ref. [7]. The applicator is designed on a FR4 substrate with height $h=5 \mathrm{~mm}$ and relative permittivity $\varepsilon_{r}=4.3$. The interdigital capacitor consists of 10 fingers with length $L_{\mathrm{f}}=18 \mathrm{~mm}$, where the width $(w)$ of each finger and the gap $(g)$ between fingers is the same: $w=g=1 \mathrm{~mm}$. The same capacitor dimensions are used for all three applicators proposed in this work. The length of inductive components (denoted in yellow in Fig. 2) is $L_{\text {ind }}=50 \mathrm{~mm}$. The interdigital capacitor is connected to the referred ground pad by four inductive air-bridges. By using the zeroth-order mode, currents flowing through the air bridges are approximately the same amplitude and phase and thus contribute significantly to the overall radiation. The micro-coplanar transmission line can be implemented with or without a ground plane. However, hyperthermia applicators must be shielded using a ground plane to suppress radiation emitted in the opposite direction of targeted human tissues.

Antennas based on MTM theory show a particular number of resonances, e.g., antennas that consist of 4 MTM cells have 9 resonances [3]. One of the main design goals for hyperthermia applicators is to achieve the best homogeneity of absorbed power in the treated tissue. Thus, it is important to excite just ZOR, since this condition ensures almost equal distribution of current, with equal phase and magnitude, to all MTM unit cells. Consequently, the contributions from each radiating element will contribute in the same proportion to the total radiated EM field. Excitation of the ZOR mode can be verified via the current density distribution on the radiating elements as shown in Fig. 3.

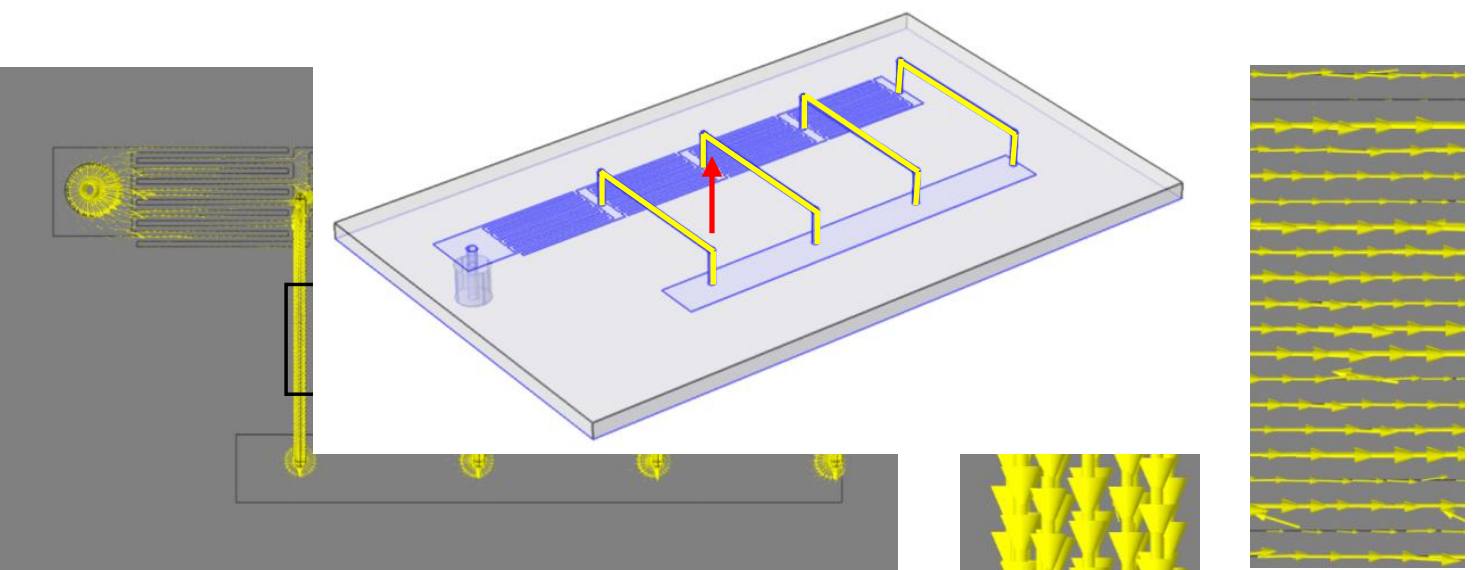


Fig. 2. Aperture view of applicator 1. The yellow out-of-plane inductive jumpers (air bridges) connect the interdigital capacitors with parallel referred ground structure. The air bridges have a height of $10 \mathrm{~mm}$ above the substrate, which extends $5 \mathrm{~mm}$ above the ground plane. Overall dimensions of the structure are $190 \times 120 \times 15.1 \mathrm{~mm}^{3}$. The red arrow shows the direction of propagation into tissue.

a)

Fig. 3. Characterization of electric currents in applicator 1. a) Surface current density, at some time instant, represented by yellow arrows on the surface of metallic conductors in applicator 1. The currents are exported from COMSOL with arrows pointing in the direction of current flow and arrowhead size linearly proportional to the magnitude of current density. b) Detail of one air bridge radiator showing nearly uniform distribution of current along the whole length of a single air bridge. c) Detail of interdigital capacitor where currents flowing from left to right are currents on the interdigital capacitors and the currents flowing from right to left are the currents on the underlying ground plane. For improved visualization, the interdigital capacitor currents are magnified three fold relative to the inductive radiating elements.

The second proposed applicator (applicator 2) is shown in Fig. 4 and is based on microstrip technology. This design allows the development of very thin and low profile applicators, which are more convenient for some clinical sites. The antenna structure consists of 4 inductive strip radiators $\left(L_{\text {ind }}=41 \mathrm{~mm}\right)$ that extend from the four finger interdigital capacitors $\left(L_{\mathrm{f}}=18 \mathrm{~mm}\right)$ to the grounded capacitive plates with dimensions of $16 \times 13 \mathrm{~mm}^{2}$. The separation $\mathrm{c} f \mathrm{f}$ radiators corresponds to the length of the unit cell and is $L=22 \mathrm{~mm}$. The input impedance of this structure at the operating frequency $434 \mathrm{MHz}$ is approximately $5 \Omega$ [8, 9]. The resulting current density along the inductive components of applicator 2 is relatively uniform as shown in Fig. 5.

b)

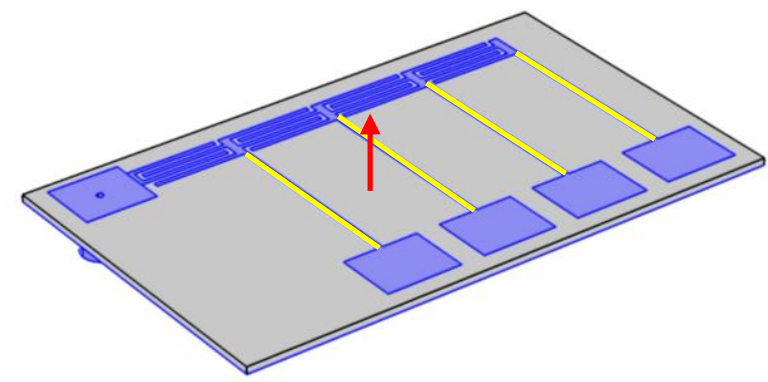

Fig. 4. Aperture view of applicator 2. This applicator is based on microstrip technology and its dimensions are $110 \times 70 \mathrm{~mm}^{2}$, with a substrate thickness of $1.5 \mathrm{~mm}$. The red arrow shows the direction of propagation into tissue.

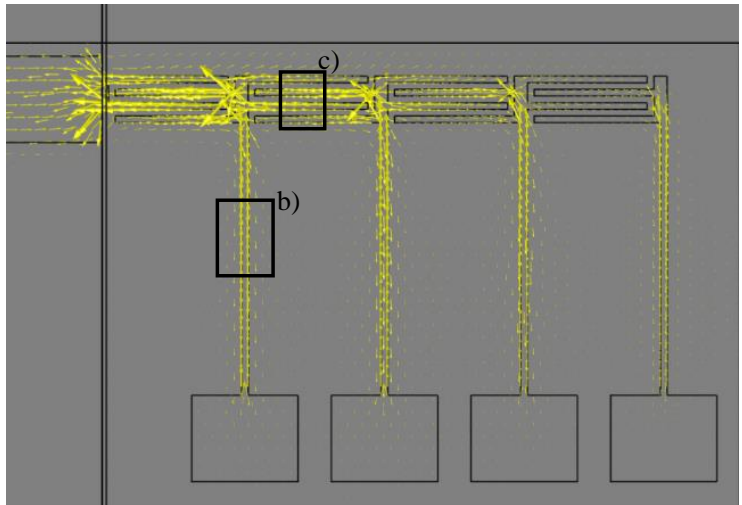

a)

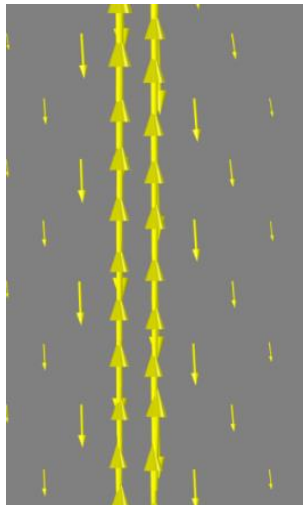

b)

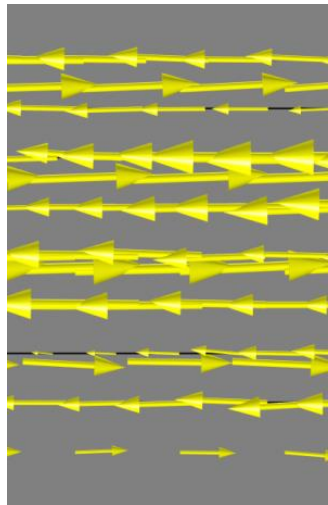

c) 
Fig. 5. Characterization of electric currents in applicator 2. a) Surface current density, at some time instant, represented by yellow arrows on the surface of metallic parts of applicator 2. b) Currents flowing from bottom to top occur in the antenna structure, while currents with the opposite orientation occur in the ground plane underlying the $1.5 \mathrm{~mm}$ thick substrate. c) Detail of one interdigital capacitor, where currents flowing from right to left occur in the interdigital capacitors and the current flowing from left to right occur in the ground plane.

The third analyzed applicator (applicator 3) is shown in Fig. 6 and was already proposed in ref. [1], where its radiation patterns were only briefly characterized. This applicator is also based on microstrip technology, but differs from applicator 2 since the space between the top metallic layer and ground plane is composed of two layers: FR4 substrate of height $h_{F R 4}=1.5 \mathrm{~mm}$ and a layer of air with height $h_{\text {air }}=68.5 \mathrm{~mm}$. In this design, the 5 vertical inductive elements (highlighted in yellow in Fig. 6) connect the upper FR4 distribution network to the lower FR4 ground plane and are responsible for generating the dominant radiation. Due to the appropriate tuning of interspersed inductive and capacitive elements, the electric currents in all five vertical elements have equal phase. This type of applicator is fed in the middle to generate symmetry in the induced power deposition pattern. Applicator 3 is shielded around all sides except the one which faces the patient. The bottom side of the applicator is shielded by a ground plane which is attached to the grounded sides, back and top shielding at distances of $1.5,7$ and $2.5 \mathrm{~cm}$ to the metallic motive, respectively. Similarly to the other two applicators, the surface current density along the inductive elements of applicator 3 shows SAR uniformity and confirms zero-order mode resonance of the structure (Fig. 7). In this type of structure it is important to maintain the same phase in all feed lines, since these contribute to the overall radiation pattern in addition to the five vertical conductors.

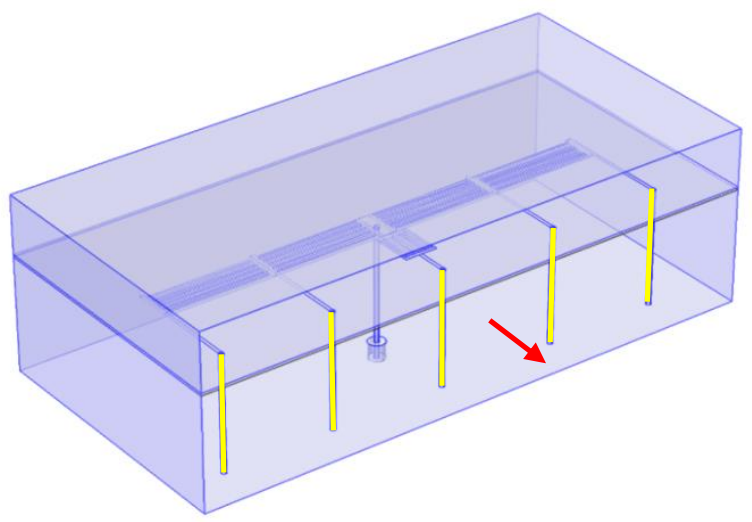

Fig.6. Applicator 3 design based on microstrip multi-layer dielectric/air substrate technology. Applicator dimensions are $277 \times 98 \times 70 \mathrm{~mm}^{3}$ [1]. The red arrow shows the direction of propagation into the treated region.
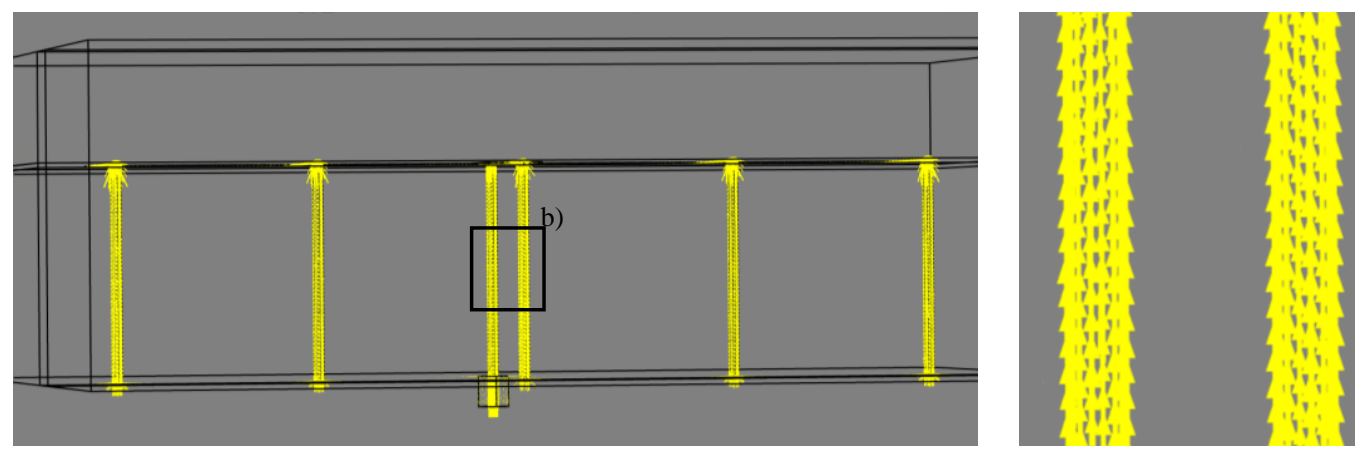
a)

Fig. 7. Characterization of electric currents in applicator 3. a) Surface current density, at some time instant, represented by yellow arrows on the surface of the metallic conductors. b) Detail of the feeding part and the middle vertical part showing uniform distribution of current.

Fig. 8. Frequency dependence of reflection coefficients for the 3 applicators under analysis.

The magnitudes of the reflection coefficient are presented in Fig. 8 as a function of frequency for all three applicators. At the desired operating frequency $434 \mathrm{MHz}$, the reflection coefficients are $-18 \mathrm{~dB},-17 \mathrm{~dB}$ and $6 \mathrm{~dB}$ for applicators 1,2 and 3, respectively. The bandwidths, defined at $-10 \mathrm{~dB}$, are $12 \mathrm{MHz}$ and $15 \mathrm{MHz}$, for applicators 1 and 2, respectively.

\section{Results}

In the numerical model, all three applicators radiate into the homogeneous muscle tissue-equivalent model through a layer of deionized water of $1 \mathrm{~cm}$ thickness representing a water bolus. While not necessary for impedance matching or for miniaturization of applicator dimensions, this water bolus is critical to cool the surface of the treated tissue volume during hyperthermia treatment. Dielectric properties of the materials considered in the numerical models are listed in Table I.

Figs. 9-11 show the s numerical simulations of power deposition distributions induced in muscle $1 \mathrm{~cm}$ under the tissue surface. Plotted contours circumscribe the regions of 75, 50 and 25 percent of maximum absorbed power in tissue at that depth. The symmetry and homogeneity of SAR depend on the distribution of current on the applicator structures. The current distribution, and thus power deposition pattern, is symmetric only in applicator 3 . In applicators 1 and 2, the symmetry of power deposition is influenced by both a nonsymmetric location of the feed point and spatial orientation of the applicator layout.

Table I

Dielectric Properties (@ 434 MHz) of Materials Considered in Numerical Models

\begin{tabular}{c|c|c|c}
\hline \hline Material & $\begin{array}{c}\text { FR4 } \\
{[12]}\end{array}$ & $\begin{array}{c}\text { De-ionized water } \\
\left(20^{\circ} \mathrm{C}\right)[13]\end{array}$ & Muscle tissue [11] \\
\hline Relative permittivity $\varepsilon_{\mathrm{r}}[-]$ & 4.2 & 80.1 & 57 \\
Equivalent conductivity $\sigma_{\mathrm{e}}[\mathrm{S} / \mathrm{m}]$ & 0.0016 & 0.047 & 0.81 \\
\hline \hline
\end{tabular}

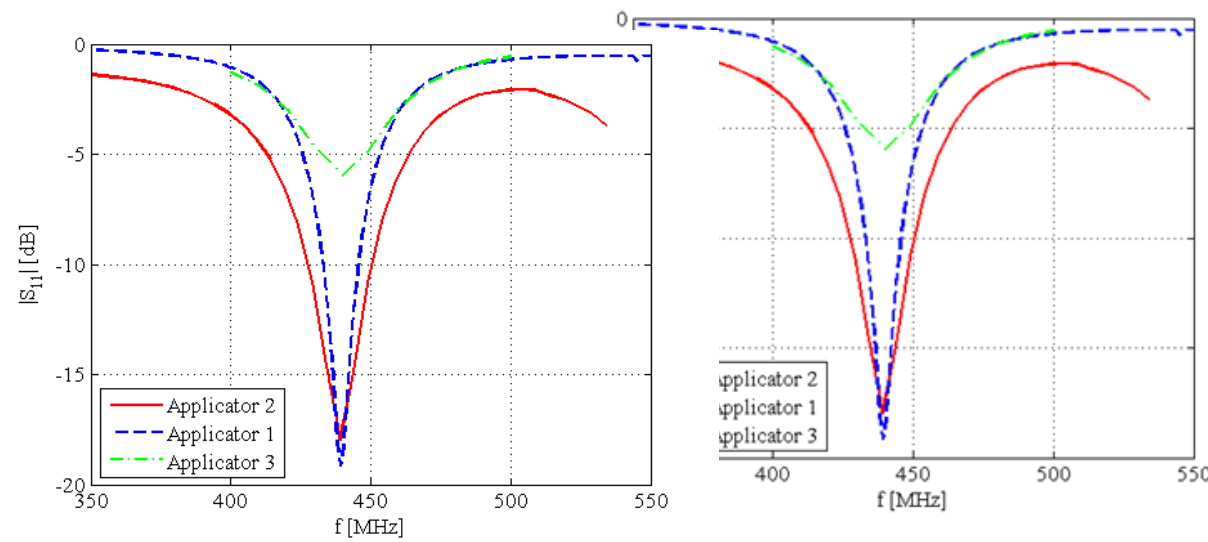

Tables II-IV list the effective field size (EFS) for three different depths in muscle tissue-equivalent model. 
EFS (Radiating Element) is defined as the ratio of area enclosed by $\mathrm{X} \%$ of maximum tissue SAR at different depths in muscle divided by the area of radiating element. EFS (Applicator) is the ratio of area enclosed by $\mathrm{X} \% \mathrm{SAR}$ divided by the total ground plane area. EFS is numerically estimated for three different levels of SAR, namely $X=25 \%, 50 \%$ and $75 \%$. All SAR levels are normalized to the maximum SAR in the $1 \mathrm{~cm}$ deep plane [10]. Due to attenuation of the EM wave in biological tissue, only the two lower levels of SAR are given in the $2 \mathrm{~cm}$ deep plane and just the $25 \%$ of SAR maximum contour results in the $3 \mathrm{~cm}$ deep plane. For applicators 1 and 2, which are designed on printed circuit board, the applicator area equal the areas of their ground planes. For applicator 3, dimensions of the radiating structure include the surrounding substrate out to the shielded metal enclosure. For completeness, the EFS related to the just the area of radiating elements is added as well. 


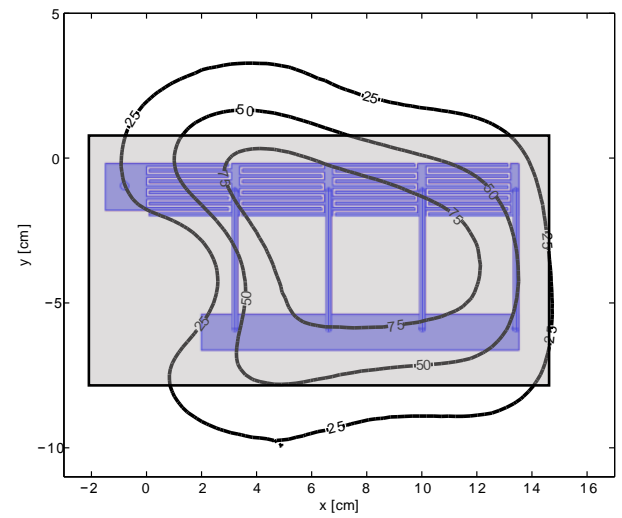

Fig. 9. Power deposition pattern $1 \mathrm{~cm}$ deep in muscle model using applicator 1.

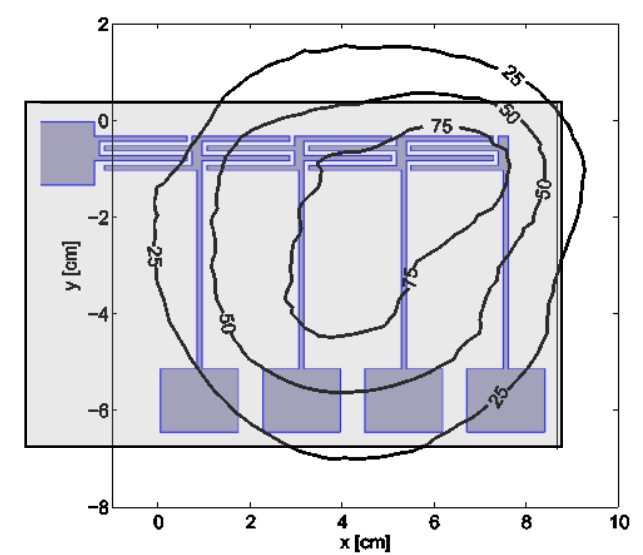

Fig. 10. Power deposition pattern $1 \mathrm{~cm}$ deep in muscle model using applicator 2 .

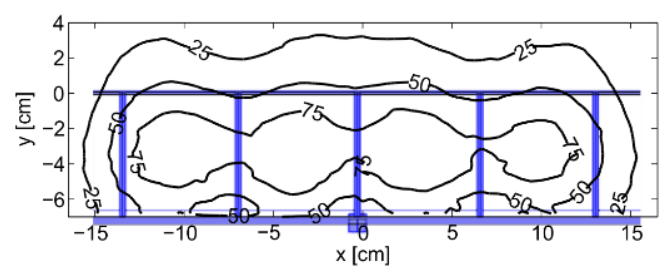

Fig. 11. Power deposition pattern $1 \mathrm{~cm}$ deep in muscle model using applicator 3 .
Table II

APPliCATOR 1 CHARACTERIZATION: EFFECTIVE FIELD SizE AND PENETRATION DEPTH

\begin{tabular}{c|c|c|c|c}
\hline \hline $\begin{array}{c}\text { Penetration } \\
\text { depth in } \\
\begin{array}{c}\text { muscle tissue } \\
(\mathrm{cm})\end{array}\end{array}$ & $\begin{array}{c}\text { SAR } \\
\text { Level } \\
(\%)\end{array}$ & $\begin{array}{c}\text { Irradiated } \\
\text { area } \geq \\
\text { SAR\% } \\
\left(\mathrm{cm}^{2}\right)\end{array}$ & $\begin{array}{c}\text { EFS } \\
\text { (Radiating } \\
\text { element }) \\
(\%)\end{array}$ & $\begin{array}{c}\text { EFS } \\
\text { (Applicator) } \\
(\%)\end{array}$ \\
\hline 1 & 75 & 46 & 45 & 20 \\
& 50 & 91 & 89 & 40 \\
& 25 & 160 & 156 & 70 \\
\hline 2 & 50 & 37 & 36 & 16 \\
& 25 & 107 & 104 & 47 \\
\hline 3 & 25 & 58 & 56 & 25 \\
\hline \hline
\end{tabular}

Table III

APPlicator 2 Characterization: EFFECTIVE FiELD Size AND PENETRATION DEPTH

\begin{tabular}{c|c|c|c|c}
\hline \hline $\begin{array}{c}\text { Penetration } \\
\text { depth in } \\
\begin{array}{c}\text { muscle tissue } \\
(\mathrm{cm})\end{array}\end{array}$ & $\begin{array}{c}\text { SAR } \\
\text { Level } \\
(\%)\end{array}$ & $\begin{array}{c}\text { Irradiated } \\
\text { area } \geq \\
\text { SAR\% } \\
\left(\mathrm{cm}^{2}\right)\end{array}$ & $\begin{array}{c}\text { EFS } \\
(\text { Radiating } \\
\text { element }) \\
(\%)\end{array}$ & $\begin{array}{c}\text { EFS } \\
(\text { Applicator }) \\
(\%)\end{array}$ \\
\hline 1 & 75 & 16 & 33 & 24 \\
& 50 & 37 & 77 & 55 \\
& 25 & 64 & 133 & 95 \\
\hline 2 & 50 & 1 & 2 & 1 \\
& 25 & 31 & 64 & 46 \\
\hline 3 & 25 & 3 & 6 & 4 \\
\hline \hline
\end{tabular}

Table IV

APPliCATOR 3 ChARACTERIZATION: EFFECTIVE FiELD Size AND PENETRATION DEPTH

\begin{tabular}{c|c|c|c|c}
\hline \hline $\begin{array}{c}\text { Penetration } \\
\text { depth in } \\
\begin{array}{c}\text { muscle tissue } \\
(\mathrm{cm})\end{array}\end{array}$ & $\begin{array}{c}\text { SAR } \\
\text { Level } \\
(\%)\end{array}$ & $\begin{array}{c}\text { Irradiated } \\
\text { area } \geq \\
\text { SAR\% } \\
\left(\mathrm{cm}^{2}\right)\end{array}$ & $\begin{array}{c}\text { EFS } \\
\text { (Radiating } \\
\text { element) } \\
(\%)\end{array}$ & $\begin{array}{c}\text { EFS } \\
\text { (Applicator) } \\
(\%)\end{array}$ \\
\hline 1 & 75 & 158 & 68 & 46 \\
& 50 & 216 & 94 & 62 \\
& 25 & 280 & 121 & 81 \\
\hline 2 & 50 & 140 & 61 & 40 \\
& 25 & 232 & 100 & 67 \\
\hline 3 & 25 & 172 & 74 & 50 \\
\hline \hline
\end{tabular}




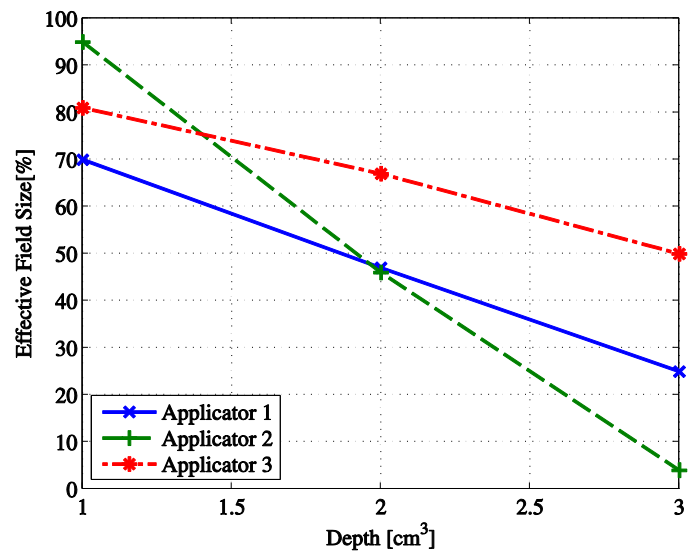

Fig. 12. Dependence of EFS (Applicator) of proposed applicators in 2D cross sectional planes 1,2 , and $3 \mathrm{~cm}$ deep in muscle model for $25 \%$ SAR level.

Similar to the evaluation of EFS in 2D cross sectional planes at depth, Tables V-VII describe the 3D volumes irradiated by the three applicators. The EFS (Radiating Element) is defined as the ratio of volume enclosed by X \% SAR contour times 1,2 or $3 \mathrm{~cm}$ depth in muscle divided by the volume of radiating element times depth. EFS (Applicator) is the ratio of volume enclosed by X \% SAR divided by the applicator aperture area times depth. The irradiated volume is normalized to the volume of muscle corresponding to the aperture face area multiplied by the target depth of 1,2 or $3 \mathrm{~cm}$ respectively. For these calculations, SAR is normalized to the maximum power deposition value within the irradiated volume.

TABLE V

\section{APPLiCATOR 1 CHARACTERIZATION: DEPENDENCE OF} EFFECTIVE FIELD Size AND PENETRATION DEPTH

\begin{tabular}{c|c|c|c|c}
\hline \hline $\begin{array}{c}\text { Penetration } \\
\text { depth in } \\
\text { muscle } \\
\text { tissue[cm] }\end{array}$ & $\begin{array}{c}\text { SAR } \\
\text { Level } \\
(\%)\end{array}$ & $\begin{array}{c}\text { Volume } \\
\left(\mathrm{cm}^{3}\right)\end{array}$ & $\begin{array}{c}\text { EFS } \\
\text { (Radiating } \\
\text { Element) } \\
(\%)\end{array}$ & $\begin{array}{c}\text { EFS } \\
\text { Applicator) } \\
(\%)\end{array}$ \\
\hline 1 & 75 & 90 & 88 & 39 \\
& 50 & 116 & 114 & 51 \\
& 25 & 192 & 188 & 84 \\
\hline 2 & 50 & 177 & 87 & 39 \\
& 25 & 324 & 159 & 71 \\
\hline \hline & 25 & 400 & 131 & 58 \\
\hline \hline
\end{tabular}

\section{TABLE VI}

APPLICATOR 2 CHARACTERIZATION: DEPENDENCE OF EFFECTIVE FIELD SizE AND PENETRATION DEPTH

\begin{tabular}{c|c|c|c|c}
\hline \hline $\begin{array}{c}\text { Penetration } \\
\text { depth in } \\
\text { muscle } \\
\text { tissue[cm] }\end{array}$ & $\begin{array}{c}\text { SAR } \\
\text { Level } \\
(\%)\end{array}$ & $\begin{array}{c}\text { Volume } \\
\left(\mathrm{cm}^{3}\right)\end{array}$ & $\begin{array}{c}\text { EFS } \\
\text { (Radiating } \\
\text { Element) } \\
(\%)\end{array}$ & $\begin{array}{c}\text { EFS } \\
\text { (Applicator) } \\
(\%)\end{array}$ \\
\hline 1 & 75 & 37 & 77 & 55 \\
& 50 & 54 & 113 & 81 \\
& 25 & 78 & 163 & 116 \\
\hline 2 & 50 & 69 & 72 & 51 \\
& 25 & 122 & 127 & 91 \\
\hline \hline & 25 & 137 & 95 & 68 \\
\hline
\end{tabular}


TABLE VII

APPlicator 3 Characterization: DePENDENCE OF EFFeCTIVE FieLd Size AND PENETRATION DEPTH

\begin{tabular}{c|c|c|c|c}
\hline \hline $\begin{array}{c}\text { Penetration } \\
\text { depth in } \\
\text { muscle } \\
\text { tissue[cm] }\end{array}$ & $\begin{array}{c}\text { SAR } \\
\text { Level } \\
(\%)\end{array}$ & $\begin{array}{c}\text { Volume } \\
\left(\mathrm{cm}^{3}\right)\end{array}$ & $\begin{array}{c}\text { EFS } \\
\text { (Radiating } \\
\text { Element) } \\
(\%)\end{array}$ & $\begin{array}{c}\text { EFS } \\
\text { (Applicator) } \\
(\%)\end{array}$ \\
\hline 1 & 75 & 135 & 58 & 39 \\
& 50 & 203 & 88 & 30 \\
& 25 & 272 & 118 & 78 \\
\hline 2 & 50 & 495 & 70 & 46 \\
& 25 & 322 & 107 & 71 \\
\hline \hline 3 & 25 & 650 & 94 & 63 \\
\hline \hline
\end{tabular}

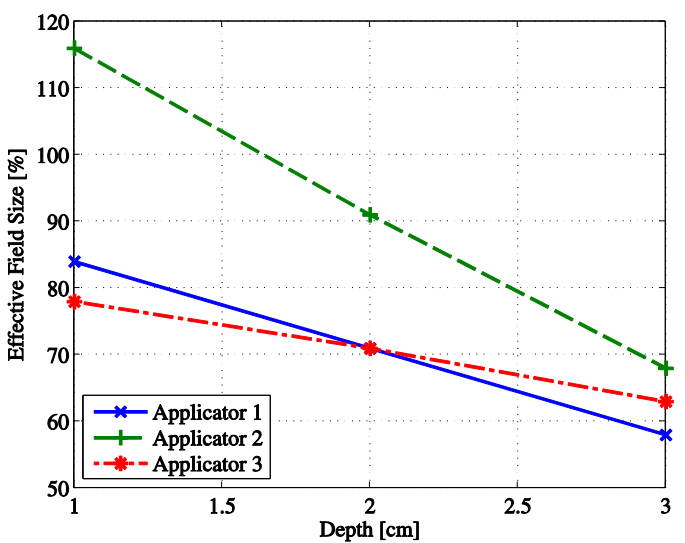

Fig. 13. Dependence of EFS (25\% SAR level) on 3D volumes irradiated by proposed applicators

\section{Discussion}

Three novel ZOR applicators were investigated in order to demonstrate their potential for the field of microwave hyperthermia. Figs. 12 and 13 show the trend of EFS decreasing with depth of penetration. These plots show the $25 \%$ of maximum SAR which is generally considered to be the minimum power deposition required for effective thermal treatment of tissue. For most uniform heating, we aim for similar EFS at all depths rather than significant slope in these curves. In this work, applicator 2 had the steepest downward trend, likely caused by the low-profile thin substrate structure which has currents on the thin ground plane running in the opposite direction of currents on the inductive radiators. Comparing applicators 1 and 3, it is readily apparent that applicator 3 has the flatter slope. For applicator 3, the cross sectional area EFS declines from $81 \%$ to $50 \%$ between the 1 and $3 \mathrm{~cm}$ deep planes, and the volume EFS reduces only from $78 \%$ to $63 \%$ in the 1 and $3 \mathrm{~cm}$ deep volumes. By comparison, the area EFS of applicator 1 declines from $70 \%$ to $25 \%$ between the $1 \mathrm{~cm}$ and $3 \mathrm{~cm}$ deep planes in muscle, and the volume EFS from $84 \%$ to $58 \%$. Evaluating the applicators from the perspective of SAR uniformity, the applicator 3 generate the most uniform heatin, filling the volume under the aperture to the greatest depth. This is due to position of the feeding point, which lies on the symmetry plane of the applicator. The other two applicators do not possess such symmetry and therefore their SAR patterns are asymmetric. In the future, the geometries of these two applicators could be modified to provide a symmetric feed location that better exploits their potential.

Although applicator 3 provides the best homogeneity, applicator 1 is thinner and can be easily fabricated on a flexible PCB, which facilitates treatment of tissues located over contoured anatomy. On the other hand, applicator 2 is easier to design and fabricate than the other two, and the EFS is still high in the 1 and $2 \mathrm{~cm}$ deep planes, which may be more suitable for superficial hyperthermia.

SAR patterns of three new applicators were evaluated in homogeneous muscle tissue models. This is a standard procedure in the field of microwave hyperthermia since the SAR patterns of new applicators are readily compared with SAR patterns of previous applicators also calculated in homogenous muscle load [REF]. Interpretation of SAR patterns in heterogeneous tissue loads is more difficult due to the high number of degrees of freedom of load anatomy and physiology. Future studies will be implemented in realistic 3D tissue models that include skin, fat, muscle and bone models. Based on EM field theory we can expect that microwave penetration will be even better in subsequent studies, since fat tissues present lower loss than 
muscle, and thus the presented patterns represent worst case penetration.

\section{Conclusions}

In this paper, three different novel applicators based on ZOR principle were introduced and characterized for potential use in microwave hyperthermia treatment of cancer. The uniformity of power deposition in muscle tissue-equivalent numerical model was assessed for all three designs and relative performance of the applicators was compared in terms of $\mathrm{S}_{11}$, uniformity and extent of SAR, as well as current distributions. The relative quality of heating of these applicators was assessed from SAR patterns in terms of effective field size in $2 \mathrm{D}$ cross sections and 3D tissue volumes under the aperture. This investigation demonstrates that applicators 1 and 3 have relatively slow change of EFS at different depths in tissue and thus appear suitable for well controlled deep heating of tissue under the MTM applicators. The ultimate choice of applicator for use in microwave hyperthermia will consider ease of design and effective penetration depth, where some applicators might be more suitable for deep targets (applicator 1 and 3) and others for superficial targets (applicator 2) such as chest wall recurrence of breast cancer.

\section{Acknowledgment}

This research has been supported by the research program of the Czech Scientific Foundation, projects no. 13- 29857P and no. 14-00386P and by EU project COST action TD1301.

\section{References}

[1] D. Vrba, and J. Vrba, "Novel Applicators for Local Microwave Hyperthermia Based on Zeroth-Order Mode Resonator Metamaterial," International Journal of Antennas and Propagation, vol. 2014, pp. 1-7, 2014.

[2] Y. Tao, and G. Wang, "Conformal hyperthermia of superficial tumor with left-handed metamaterial lens applicator," IEEE Transactions on Biomedical Engineering, vol. 59, no. 12, pp. 3525-3530, Dec, 2012.

[3] C. Caloz, and T. Itoh, Electromagnetic Metamaterials: Transmission Line Theory and Microwave Applications: The Engineering Approach, New Jersey: John Wiley \& Sons, 2006.

[4] D. Vrba, and M. Polivka, "Radiation Efficiency Improvement of Zeroth-Order Resonator Antenna," Radioengineering, vol. 18, no. 1, pp. 1-8, Apr, 2009.

[5] Alley,G.D.,"Interdigital Capacitors and Their Applications to Lumped Ellement Microwave Integrated Circuit," IEEE Transactions on Microwave Theory and Techniques, Vol.MTT-18,No.12,December 1970, pp.1028-1033.

[6] F.E. Terman, "Radio Engineers' Handbook," London, McGraw-Hill, 1st ed., Sep. 1950

[7] M. Polivka, and D. Vrba, "Shielded Micro-Coplanar CRLH TL Zeroth-Order Resonator Antenna: Critical Performance Evaluation," Radioengineering, vol. 18, no. 4, pp. 368-372, Dec, 2009.

[8] A. Sanada, M. Kimura, I. Awai, C. Caloz, and T. Itoh, "A planar zeroth-order resonator antenna using a left-handed transmission line," 34th European Microwave Conference, Vols 1-3, Conference Proceedings, pp. 1341-1344, 2004.

[9] M. Polivka, and D. Vrba, "Input Resistance of Electrically Short Not-Too-Closely Spaced Multielement Monopoles With Uniform Current Distribution," IEEE Antennas and Wireless Propagation Letters, vol. 11, pp. 1576-1579, 2012.

[10] G. C. Van Rhoon, P. J. M. Rietveld, and J. Van der Zee, "A $433 \mathrm{MHz}$ lucite cone waveguide applicator for superficial hyperthermia," International Journal of Hyperthermia, vol. 14, no. 1, pp. 13-27, Jan-Feb, 1998.

[11] P. A. Hasgall, E. Neufeld, M. C. Gosselin, A. Klingenböck, and N. Kuster, "IT'IS Database for thermal and electromagnetic parameters of biological tissues," 2011. [Online] Available: www.itis.ethz.ch/database.

[12] ISOLA. (2014) ISOLA 370HR datasheet. [Online]. Available: www.isola-group.com/products/370hr/.

[13] W. J. Ellison, "Permittivity of pure water, at standard atmospheric pressure, over the frequency range 0-25 THz and the temperature range 0-100 degrees C," Journal of Physical and Chemical Reference Data, vol. 36, no. 1, pp. 1-18, Mar, 2007. 